http://dx.doi.org/10.11646/zootaxa.3619.1.2

http://zoobank.org/urn:1sid:zoobank.org:pub:2DE3643D-DB51-412F-9414-865A9D953853

\title{
The reptile type specimens preserved in the Museo Nacional de Ciencias Naturales (CSIC) of Madrid, Spain
}

\author{
TERESA GARCÍA-DÍEZ1 \& JOSÉ E. GONZÁLEZ-FERNÁNDEZ² \\ ${ }^{1}$ Fauna Ibérica Project, Museo Nacional de Ciencias Naturales (CSIC), c/ José Gutiérrez Abascal 2, 28006 Madrid, Spain. \\ E-mail: teresagarciadiez@gmail.com \\ ${ }^{2}$ Department of Biodiversity and Evolutionary Biology. Museo Nacional de Ciencias Naturales (CSIC), c/ José Gutiérrez, Abascal 2, \\ 28006 Madrid, Spain. E-mail: jegonzalez@mncn.csic.es
}

\begin{abstract}
A first complete list of the reptile type specimens preserved in the Museo Nacional de Ciencias Naturales (CSIC) of Madrid (updated until 15 July 2012) is provided. The collection houses a total of 319 type specimens representing 24 taxa belonging to 6 families and 12 genera. There are 22 taxa represented by primary types (19 holotypes, 2 neotypes and 1 lectotype) and at least one paratype, and only two taxa are exclusively represented by one secondary type (paratype). The collection is specially rich in Spanish endemisms. Special attention is deserved by the type series of many subspecies of Podarcis lilfordi described by A. Salvador and V. Pérez-Mellado. All type specimens are housed in the Herpetological collection except Blanus mariae and Psammodromus occidentalis type series and Psammodromus hispanicus (neotype) which are preserved in the DNA/Tissues Collection.
\end{abstract}

Key words: Reptilia, Type specimens, Scientific collections, Museological catalogue, Museo Nacional de Ciencias Naturales, Spain

\section{Introduction}

The Royal Cabinet of Natural History, currently Museo Nacional de Ciencias Naturales of Madrid (MNCN), was founded in 1771 by the king Carlos III with the acquisition of the Pedro Franco Dávila's cabinet. It was not the first world-founded modern museum, but it was the first in opening its exhibitions to the public, exactly on November 1776 (Barreiro, 1992).

The amphibian and reptile collection of the MNCN preserves a few specimens of this old cabinet, among them six naturalised large sea turtle specimens (three males and three females) of Caretta caretta (Linnaeus, 1758), Chelonia mydas (Linnaeus, 1758) and Eretmochelys imbricata (Linnaeus, 1766), brought to Spain in 1793 by Antonio Parra from Cuba (González-Fernández \& García-Díez, 2010). These specimens can be considered as the first reptiles of the Herpetology collection of the MNCN.

It was after the Spanish-French war (1808-1812) when the Royal collection begun to grow. In 1835, Ramón de la Sagra came back from Cuba with herpetological material collected by himself and by Dr. Poey between 1823 and 1835. Unfortunately the most interesting specimens collected by de la Sagra were sent to the Muséum National d'Histoire Naturelle of Paris to be studied by Cocteau and Bibron. These authors used these specimens to describe several new reptile species from Cuba, as for example, Ameiva auberi Cocteau, 1838, Diploglossus delasagra (Cocteau, 1838), Epicrates angulifer Bibron, 1843, Tropidophis maculatus (Bibron, 1843), etc., but the specimens were never returned to the MNCN.

The type collection of the MNCN could have started with Marcos Jiménez de la Espada. This famous herpetologist, a member of the Pacific Scientific Commission (1862-1865), collected a lot of amphibians and reptiles in America. Between 1871 and 1875 he described some new Neotropical amphibian taxa: 1 family, 12 genera and 36 species and subspecies. Currently, 672 of these amphibians are preserved in the MNCN, and 128 of them are type specimens (González Fernández 2000; 2006; González-Fernández et al., 2009). It is possible that, if 